\title{
FAKTOR-FAKTOR YANG MEMPENGARUHI KEPUTUSAN PEMBELIAN KAMAR MELALUI ONLINE TRAVEL AGENT DI RAISING HOTEL MAKASSAR
}

\author{
Riska Veronika ${ }^{1)}$, Anggun Sari Sasmita ${ }^{2)}$ Dewi Andriani ${ }^{3)}$ \\ 1) Program Studi Perhotelan, Politeknik Bosowa \\ 2) Program Studi Perhotelan, Politeknik Bosowa \\ 3) Program Studi Perhotelan, Politeknik Bosowa
}

09 November 2018

\begin{abstract}
In hotel management, room booking can be done by the guests with a manually or online through the hotel website or online travel agent. Online travel agent sale room an application or website. The research objective is to determine the factors that influence purchase decision of room through online travel agent at Raising Hotel Makassar. In this study, data collection techniques using are observation, questionnaire and literature study. The survey results is shows that all factors give the influence of the purchase decision of the room thourgh online travel agent at Raising Hotel Makassar. It can be concluded that purchase decision is effectly culture factor with an average value of 3.50, Social factor with an average value of 3.53, Personal factor with an average value of 3.64. the most dominant influen is a pscyhological factor, with the highest value on average is 4.16
\end{abstract}

Keyword: Puchase Decision, Reservation, Online Travel Agent

\begin{abstract}
ABSTRAK
Dalam manajemen hotel, pemesanan kamar dapat dilakukan oleh para tamu dengan secara manual atau online melalui situs web hotel atau agen perjalanan online. Agen penjualan online kamar aplikasi atau situs web. Tujuan penelitian adalah untuk mengetahui faktor-faktor yang mempengaruhi keputusan pembelian kamar melalui agen perjalanan online di Raising Hotel Makassar. Dalam penelitian ini, teknik pengumpulan data yang digunakan adalah observasi, angket dan studi pustaka. Hasil survei menunjukkan bahwa semua faktor memberikan pengaruh keputusan pembelian kamar dari agen perjalanan online di Raising Hotel Makassar. Dapat disimpulkan bahwa keputusan pembelian adalah faktor budaya yang berpengaruh dengan nilai rata-rata 3,50, Faktor sosial dengan nilai rata-rata 3,53, Faktor pribadi dengan nilai rata-rata 3,64. influen yang paling dominan adalah faktor psyologis, dengan nilai tertinggi rata-rata adalah 4,16 .
\end{abstract}

Kata kunci: Keputusan Pembelian, Reservasi, Travel Agent Online

\section{PENDAHULUAN}

Peningkatan wisatawan mancanegara dan wisatawan domestik juga berdampak pada perkembangan usaha akomodasi. Hotel termasuk dari akomodasi, hotel dikategorikan menjadi dua yaitu hotel berbintang dan hotel non bintang. Hotel berbintang dari tahun ke tahun di Sulawesi Selatan semakin meningkat. Hal tersebut dibuktikan dari tahun 2010 jumlah usaha akomodasi untuk hotel berbintang sebanyak 1.306 hotel pada tahun 2011 terdapat 1.489 hotel. Berikutnya di tahun 2012 terdapat 1.623 hotel dan pada tahun 2013 terdapat 1.778 hotel serta tahun 2014 jumlah mencapai 1.996 hotel (BPS, 2015)

Pada pengelolaan jasa hotel, pemesanan kamar dapat dilakukan oleh tamu dengan cara manual seperti pemesanan kamar melalui telepon maupun melalui website atau Online Travel Agent. Online Travel Agent merupakan agen perjalanan dalam bentuk penjualan online dengan menggunakan aplikasi ataupun melalui website, mendukung tamu untuk memesan kamar salah satunya adalah Online Travel Agent dalam pembelian kamar hotel. Proses pemesanan kamar 
melalui Online Travel Agent di beberapa hotel dengan menggunakan voucher pada saat pembayaran telah selesai melalui Online Travel Agent.

Beberapa Online Travel Agent yang saat ini, banyak melakukan kerjasama dengan beberapa hotel antara lain, Traveloka, Pegi-Pegi.com, Agoda dan Nida Rooms. Salah satu hotel yang berkerjasama dengan online travel agent adalah Raising Hotel Makassar merupakan hotel berbintang 3 yang berdiri pada tanggal 21 Juni 2015.

Raising Hotel Makassar berada bawah naungan PT Lima Benua Persada. Jumlah kamar yang beroperasi di Raising Hotel Makassar saat ini adalah 68 kamar dari 5 jenis tipe kamar. Raising Hotel Makassar menerima beberapa jenis pemesanan kamar seperti, pemesanan kamar melalui telepon, pemesanan kamar melalui offline travel agent, pemesanan kamar melalui website resmi Raising Hotel Makassar dan juga reservasi melalui Online Travel Agent.

Pendapatan utama dari Raising Hotel Makassar berasal dari penjualan kamar. Penjualan kamar melalu Online Travel Agent di Raising Hotel Makassar merupakan pendapatan yang membantu peningkatan dan penjualan kamar setiap harinya. Dengan adanya hal tersebut, penulis mencari faktor-faktor yang mempengaruhi keputusan pembelian kamar melalui online travel agent dan faktor dominan yang mempengaruhi faktor keputusan pembelian kamar dapat memberikan masukan untuk Raising Hotel Makassar mengetahui faktor yang dapat dijadikan acuan dalam penjualan kamar untuk menambah presentase kamar di Raising Hotel Makassar setiap harinya, sehingga penulis mengangkat judul penelitian ini sebagai berikut "Faktor-faktor yang Mempengaruhi Keputusan Pembelian Kamar Melalui Online Travel Agent di Raising Hotel Makassar"

\section{IDENTIFIKASI MASALAH}

Berdasarkan latar belakang masalah tersebut maka rumusan masalah dalam penelitian sebagai berikut : Apa saja faktor-faktor yang mempengaruhi keputusan pembelian kamar melalui Onlien Travel Agent di Raising Hotel Makassar?

\section{METODOLOGI PENELITIAN}

Metode penelitian yang digunakan oleh penulis adalah metode kuantitatif. Teknik pengumpulan data dalam penelitian ini menggunakan angket, observasi dan studi pustakan. Populasi dalam penelitian ini seluruh tamu dalam 2 bulan terakhir (Mei-Juni 2017) di Raising Hotel Makassar. Teknik pengambilan sampel yang digunakan adalah insidental sampling dengan menggunakan rumus Ferdinand dengan total sampel sebesar 70 responden.

\section{Skala Pengukuran Data}

Setelah semua data terkumpul, langkah selanjutnya yang dilakukan oleh peneliti yaitu melakukan perhitungan dari hasil angket yang telah diisi oleh responden yang telah dipilih. Dalam penelitian ini, penulis menggunakan skala likert. Skala likert digunakan untuk mengukur sikap, pendapat, dan persepsi seseorang atau sekelompok orang tentang fenomena sosial. Sebelumnya, penulis telah menetapkan variabel penelitian yang kemudian akan diukur dan dijabarkan menjadi indikator variabel. Setelah itu, indikator tersebut dijadikan sebagai titik tolak untuk menyusun item-item instrumen yang dapat berupa pernyataan atau pertanyaan (Sugiyono, 2015). Skala likert digunakan oleh peneliti dalam mengukur keputusan pembelian di Raising Hotel Makassar. Berikut adalah tingkat nilai dalam penelitian dengan menggunakan skala likert:

Tabel 1.1 Skala Likert

\begin{tabular}{lll}
\hline Skala & Nilai & Kode \\
\hline Sangat Setuju & 5 & SS \\
\hline Setuju & 4 & ST \\
\hline Ragu-ragu & 3 & RG \\
\hline Tidak Setuju & 2 & TS \\
\hline $\begin{array}{l}\text { Sangat tidak } \\
\text { setuju }\end{array}$ & 1 & STS \\
\hline \multicolumn{2}{c}{ Sumber : Sugiyono, 2015}
\end{tabular}

\section{Teknik Analisis Data}

Menurut Sujarweni, 2014, analisis data dapat diartikan sebagai upaya data yang sudah tersedia kemudian diolah dengan statistik deskriptif dan dapat digunakan untuk menjawab rumusan masalah dalam penelitian. Analisis data yang 
digunakan dalam penelitian ini adalah statistik deskriptif.

Statistik deskriptif adalah statistik yang digunakan untuk menganalisis data dengan cara mendiskripsikan atau menggambarkan data yang telah terkumpul sebagaimana adanya tanpa bermaksud membuat kesimpulan yang berlaku untuk umum atau generalisasi (Sugiyono,2015).

\section{HASIL PENELITIAN DAN PEMBAHASAN}

Pembahasan hasil penelitian adalah penelitian adalah penjelasan mengenai analisis hasil mengenai faktor-faktor yang mempengaruhi keputusan pembelian kamar melalui online travel agent di Raising Hotel Makassar untuk menjawab rumusan masalah pada bab sebelumnya. Penilaian variabel didasarkan pada tanggapan tamu hotel sebagai responden yang memberikan sesuai dengan pernyataan yang di ajukan dalam angket dan juga dari hasil perhitungan aplikasi 22.0.

Berikut merupakan rata-rata dari angket secara keseluruhan:

\section{Gambar: 1.1 Diagram Hasil Angket}

Berdasarkan hasil penelitian yang telah disajikan pada Gambar 4.1 bahwa faktor budaya, sosial, pribadi memilki nilai rata-rata yang hampir sama, yang artinya bahwa ketiga sub variabel berpengaruh terhadap keputusan pembelian kamar melalui online travel agent di Raising Hotel Makassar dan dapat diketahui untuk menjawab rumusan masalah mengetahui faktor dominan yang mempengaruhi keputusan pembelian kamar melalui online travel agent di Raising Hotel Makassar adalah faktor psikologis dengan nilai rata-rata 4.39 yang dimana seluruh pernyataan menyatakan setuju dari 3 butir pernyataan.

\section{Faktor-faktor yang mempengaruhi keputusan pembelian kamar melalui Online Travel Agent di Raising Hotel Makassar}

Dalam penelitian ini, terdapat empat faktor yang diteliti yang memiliki pengaruh terhadap keputusan pembelian diukur dengan 4 sub variabel yaitu, faktor budaya, faktor sosial, faktor pribadi dan faktor psikologis.

Sub variabel pertama yaitu faktor budaya, memiliki 3 indikator yaitu budaya, sub budaya dan kelas sosial. Hasil penelitian menunjukkan indikator budaya memiliki nilai mean tertinggi dari beberapa indikator lainya dengan nilai sebesar 3.96. Berdasarkan data tersebut, dapat dilihat budaya konsumen saat ini dipengaruhi oleh perkembangan teknologi sehingga menjadikan kebiasaan seseorang menggunakan aplikasi online dengan membeli produk ataupun jasa, sehingga dapat disimpulakan bahwa perilaku dasar dari seseorang di ambil dari kebiasaan yang dilakukan di aktifitas sehari-hari.

Sub variabel kedua yaitu faktor sosial, faktor sosial memiliki 2 indikator yaitu kelompok acuan dan keluarga. Hasil penelitian tersebut menunjukan indikator keluarga memiliki nilai mean tertinggi dengan nilai sebesar 3.81 dari kelompok acuan. Berdasarkan data tersebut, indikator keluarga merupakan memberikan pengaruh yang baik untuk membeli suatu produk, karena adanya kepercayaan kepada keluarga yang dikenal ataupun keluarga orientas. Sehingga dapat disimpulkan bahwa adanya kepercayaan

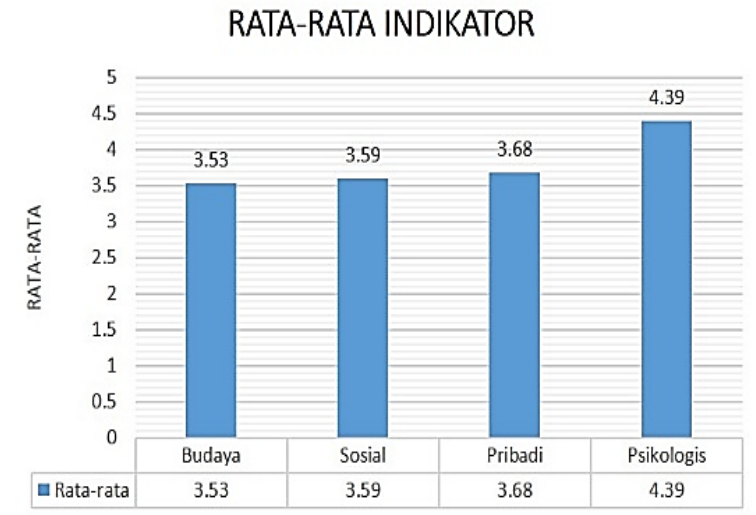

kepada keluarga sehingga mempengaruhi keputusan pembelian, karena saling mempengaruhi apa yang telah mereka rasakan setelah merasakan produk tersebut dan saling mempengaruhi di dalam keluarga.

Sub variabel ketiga faktor pribadi, faktor pribadi memiliki 3 indikator yaitu usia dan siklus hidup keluarga, pekerjaan dan lingkungan ekonomi dan gaya hidup. Hasil penelitian tersebut menunjukkan indikator gaya hidup 
memiliki nilai mean tertinggi dengan nilai mean sebesar 4.22 pada faktor pribadi. Gaya hidup dapat diartikan sebuah pola hidup seseorang dalam menjalankan aktifitas dan minatnya. Gaya hidup juga mempengaruhi keputusan pembelian seseorang melalui pola hidup yang mencerminkan seseorang dalam kegiatan sehariharinya.

Sub variabel faktor psikologis, memiliki 3 indikator yaitu motivasi, persepsi dan pembelajaran. Hasil penelitian tersebut menunjukkan indikator motivasi memiliki nilai mean tertinggi dengan nilai mean sebesar 4.23 pada faktor psikologis. Motivasi merupakan suatu kebutuhan yang mendesak untuk mengarahkan konsumen untuk membeli suatu produk ataupun jasa. Motivasi mempengaruhi adanya dorongan yang diberikan sehingga dapat membeli produk tersebut, dapat disimpulkan bahwa motivasi juga dapat mempengaruhi keputusan pembelian karena adanya arahan yang diberikan dari seseorang.

\section{Faktor dominan yang mempengaruhi keputusan pembelian melalui online travel agent di Raising Hotel Makassar.}

Faktor dominan yang mempengaruhi keputusan pembelian kamar melalui online travel agent adalah sub variabel faktor psikologis dapat dilihat seluruh pernyataan dari indikator faktor psikologis dengan nilai rata-rata 4.23. Dilihat dari faktor psikologis pertama yaitu motivasi proses timbulnya dorongan sehingga konsumen tergerak untuk membeli suatu produk. Tamu memesan kamar melalui dorongan karena adanya motivasi. Persepsi didefinisikan sebagai proses dimana seseorang memilih, mengorganisasikan, mengartikan, masukan informasi untuk menciptakan gambaran keputusan pembelian kamar melalui online travel agent. pembelejaran dalam keputusan pembelian didefinisikan bahwa pembelajaran merupakan perilaku yang relatif permanen disebabkan karena pengalaman konsumen dalam melakukan transaksi online, termasuk dalam melakukan pembelian kamar dengan menggunakan online travel agent. Hal ini sejalan dengan teori yang dikemukakan Kotler, keputusan pembelian konsumen dipengaruhi oleh empat faktor yaitu faktor budaya, faktor sosial, faktor pribadi dan faktor psikologis dari pembeli.
Sebagian besar adalah faktor-faktor yang tidak dapat dikendalikan oleh pemasar, tetapi harus benar-benar diperhitungkan.

Faktor Psikologis juga menjadi pilihan keputusan pembelian karena dipengaruhi faktor utama yaitu, motivasi merupakan kebutuhan yang mendorong seseorang secara kuat mencari kepuasan atas kebutuhan tersebut, persepsi merupakan bagaimana menyeleksi informasi guna membentuk gambaran yang berarti, pembelajaran merupakan meliputi perubahan perilaku seseorang karena pengalaman, dan keyakinan sikap pemikiran deskriptif yang dipertahankan seseorang mengenai sesuatu.

Dilihat dari keputusan pembelian yang dilakukan oleh responden, dapat digambarkan bahwa tamu melakukan keputusan untuk membeli kamar hotel karena adanya pengaruh psikologis. Mereka menjadikan aplikasi online sebagai kebutuhan transaksi pembelian kamar hotel. Responden menjadikan aplikasi online travel agent sebagai bahan pertimbangan pada saat mereka ingin melakukan pembelian kamar hotel. Responden merasa keputusan pembelian kamar melalui Online Travel Agent merupakan pilihan yang tepat.

\section{SIMPULAN}

Berdasarkan hasil penelitian dan pembahasan terhadap data yang dilakukan peneliti, diperoleh suatu kesimpulan bahwa:

1) Faktor-faktor yang mempengaruhi keputusan pembelian kamar melalui Online Travel Agent di Raising Hotel Makassar diambil berdasarkan hasil angket dari 70 responden selaku tamu Online Travel Agent di Raising Hotel Makassar yang terdiri dari 18 pernyataan dengan 4 indikator maka dapat disimpulkan bahwa faktor-faktor yang mempengaruhi keputusan pembelian kamar melalui Online Travel Agent di Raising Hotel Makassar adalah faktor budaya, faktor sosial, dan faktor pribadi.

Faktor dominan yang mempengaruhi keputusan pembelian kamar melalui online travel agent di Raising Hotel Makassar dilihat dari hasil angket dengan nilai rata-rata indikator yang paling tinggi. Faktor dominan tersebut adalah faktor psikologis dengan seluruh kriteria pernyataan 
menyatakan setuju. Indikator ini memperoleh nilai rata-rata yang paling tinggi di antara yaitu sebanyak 4.39.

\section{DAFTAR PUSTAKA}

Aribowo, Dwi Putra Jati dan Mahendra Adhi Nugroho. (2013). Pengaruh Trust dan Perceived of Risk Terhadap Niat untuk Transaksi untuk Bertransaksi Menggunakan E-Commerce.Jurnal Nominal Vol. II no.1. Fakultas Ekonomi Universitas Negeri Yogyakarta. Di akses di

https://media.neliti.com/media/publicati ons/191146-ID-none.pdf

Badan Pusat Statistik. (2016). "Peningkatan Jumlah Wisatawan Domestik dan Wisatawan Mancanegara" www.bps.go.id. (Rujukan Online)

Hadi, Prasetyo dan Sumarto. (2011). Mempertahankan Loyalitas Pelanggan E-Commerce. Prosiding Seminar Nasional Manajemen Teknologi XIII. Program Studi MMT-ITS, Surabaya. Di akses http://mmt.its.ac.id/publikasi/?p=2322

Kotler Philip. (2016). "Manajemen Pemasaran". Erlangga. Jakarta (Rujukan buku)

Morrison, M. Alastair. (2010). Hospitality \& Travel Marketing $4^{\text {th }}$ Edition.Delmar Cencage Learning. Canada.

Pradiatiningtyas Diah, (2015), Jurnal “Analisa Buying Behavior pada Online Travel Agent" http://ejournal.bsi.ac.id

Sugiyono. (2015). "Metodologi Penelitian Komperenhensif". Alfabeta. Yogyakarta (Rujukan buku)

Sujarweni. (2014). "Metodologi Penelitian" Alfabet. Yogyakarta. (Rujukan buku 